\title{
"Slippery" Work Surfaces: Towards a Performance Definition and Quantitative Coefficient of Friction Criteria
}

\author{
James M. Miller
}

\begin{abstract}
There have been 50 years of research in walking/working surface slipperiness and coefficient of friction (COF) measurements. Nevertheless, numerous standards address slip/fall accidents only in terms of requiring surfaces to be qualitatively "nonslippery." The literature useful for establishing quantitative criteria for "slippery" vs. "slip-resistant" have been summarized here. A performance definition for "slippery work surfaces" is proposed. Recommendations applicable to standards-making organizations are made, including changing terms such as "non-slip" to "slip-resistant" and defining "slippery" in terms of quantitative COF values. For persons walking unloaded on level surfaces, a COF standard of 0.5 would be reasonable. Research is recommended to determine if "slip-resistance" requirements and accident prevention could be achieved more easily be controlling the type of shoe, type of task, or amount of surface contaminant rather than controlling only the COF of the basic surface and its coating.
\end{abstract}

In at least 30 places in 29 CFR (Code of Federal Regulations) Parts 1910 and 1926 (Occupational Safety and Health Act, 1970) there are requirements for employers to provide work surface conditions that will protect workers against slip/fall accidents. These provisions were adopted almost unchanged from numerous existing ANSI (American National Standards Institute) standards, which set

James M. Miller, P.E., Ph.D., is an Associate Professor of Industrial and Operations Engineering, Center for Ergonomics and Safety, The University of Michigan, Ann Arbor, MI 48109.

The research for this paper was supported in part by the Directorate of Safety Standards, Occupational Safety and Health Administration, U.S. Department of Labor. The opinions herein are those of the author and do not necessarily represent those of the Department of Labor. forth performance requirements for steps, ladders, walkways, platforms, floors, treads, footwalks, plank walkways, foot pedals, rungs, and decks. The Occupational Safety and Health Administration (OSHA) regulations use the mandatory "shall" in stipulating the anti-slip/fall characteristics that such surfaces are to have. This "shall" appears in conjunction with descriptors such as slip-resistant, nonslip, nonskid, nonslippery, anti-slip, safe footing, and adequate footing. Many of these terms seem to be used almost interchangeably in the OSHA standards. Similar language occurs to a lesser extent in other government and consensual standards.

At only one point in the OSHA anti-slip/ fall regulations is any quantitative requirement specified. This is in reference to "Man- 
lifts" in 29 CFR 1910.68 (c) (3) (v), which states "The upper or working surfaces of the step shall be of a material having inherent nonslip characteristics (coefficient of friction not less than 0.5 ) ..."

Nowhere in the OSHA regulations, however, are there provisions for or reference to recommended methods for making quantitative measurements of a coefficient of friction (COF). Further, there are no guidelines to provide the employer with benchmark information about what types of surfaces or circumstances might be expected to yield noncomplying anti-slip/fall conditions. This situation has led to the following problems:

1. Neither private employers nor government compliance officials are able to interpret and apply the anti-slip/fall provisions of OSHA and other government standards.

2. Officials in OSHA and other government organizations do not know how to remedy the vagueness of this performance language in their own regulations.

\section{The Traditional Research Questions}

Since the early 1930 's, government and private researchers in the United States and Europe have been striving to quantitatively describe the interaction that occurs between the shoe sole (or foot) and surface. These shoe/surface interactions occur during walking, climbing, turning, pushing, pulling and other tasks. Researchers agree that these interactions are a function of the shoe sole, surface, environment, task, and method of shoel surface contact. It is also generally agreed that the interaction causing people to slip is best quantitatively described using coefficient of friction measures. Although a lew researchers subscribe to the use of subjective ratings based on the "feeling of slipperiness," the majority believe that the physically measured coefficient of friction (COF) is closely correlated with the tendency to slip. Beyond this general agreement, obtaining further consensus becomes considerably more difficult. Instead of resolving the issues, 50 years of research have often brought inconsistent results and differing opinions. The following questions have persisted in the past and are still of research interest today:
1. Do walking, turning, climbing, pushing, and pulling involve the static or dynamic COF phenomenon or some combination?

2. Do the COF testing machines used to gather early or recent data measure dynamic or static COF?

3. Do all shoe/surface combinations have both static and dynamic COF values that are separately identifiable?

4. How does dynamic COF vary with the slipping speed between the shoe sole and surface?

5 . Which testing machines yield the most reproducible and accurate results for laboratory tests or for field tests on in-service work surfaces?

6. What COF values are necessary to counteract the horizontal forces generated by a person's walking, climbing, turning, pushing, pulling, etc.?

7 . What COF values are necessary to prevent persons from slipping as a function of the type of task performed?

8. What COF values can one typically expect for various combinations of shoe soles, surfaces, and contaminant conditions (oil, water, and dirt)?

\section{The Policy Dilemma}

The above questions have not been resolved to anyone's satisfaction. Thus, government standards-making organizations (e.g., OSHA) have elected not to clarify their standards by requiring quantitative $\mathrm{COF}$ values for various walking/working/climbing surfaces. The difficult policy question has become: Is the preponderance of factual material now sufficient for more substantive rulemaking on anti-slip/fall provisions within standards?

If the answer is "yes," then government policy-makers must establish, modify, clarify, or interpret the standards in a way that will be viewed by the public as being: (1) effective in reducing slip/fall type injuries; (2) technologically feasible; (3) practically achievable; (4) capable of reasonable enforcement; and (5) not an economic burden to employers.

If the answer is "no," then we must sadly admit that little progress has been made over the past 50 years with respect to COF-related accident prevention. With such a negative 
conclusion, we are admitting the inability to provide assistance to employers who want to comply if they are only told what "anti-slip," "nonslip," and "slip-resistance" mean. The problem goes beyond employers not knowing how to comply. It extends to the compliance officers who don't know how to interpret the performance language in these standards for enforcement purposes. As a result we have contributed little to addressing where one in about every five occupational accidents occurs.

Between 1970 and now there have been efforts by the National Institute for Occupational Safety and Health (NIOSH) and the National Bureau of Standards (NBS) to help further the development of the COF-related OSHA standards and their enforcement. Unfortunately, this research has left OSHA and other standards-making organizations with two unresolved problems.

First, the results of these efforts barely went beyond laying out recommendations for further research. The implication was that such research would be necessary before decisions leading to supportable standards could be made. Nevertheless, a recommendation to do only further research and development leaves a regulatory agency in an awkward position, particularly if there is pressure to show regulatory progress and that agency has the desire to so respond.

The second problem that OSHA and other government agencies face is the difficulty in integrating the wide range of COF research in the literature. To be useful it must be in a form appropriate to use as a basis for modifying the existing slip/fall standards. This is necessary because of the requirement for well documented background and justification preambles to accompany any proposed government actions such as rulemaking. Publication in the Federal Register of such preambles is required to allow for critical public review by those affected. An inadequate or inappropriate rationale given for any government action will most assuredly be the subject of challenge.

This paper will assist in resolving the above problems by showing that: (1) the "preponderance of evidence" is sufficient at this time to initiate additional standards-related activi- ties $^{1}$ in the slip/fall area; and (2) the literature can be integrated into a form that is useful for justifying such proposed actions.

\section{CONCLUSIONS FROM THE LITERATURE}

\section{Qualitative Recommendations}

Over the past 25 years there have been six key publications that in the author's opinion best capture the history of COF research. They also provide significant regulatory policy implications. These documents are as follows: Federal Construction Council, $\mathrm{Na}$ tional Academy of Sciences (1961); Reed (1975); Pfauth and Miller (1976); Brungraber (1976); Adler and Pierman (1979); and James (1980).

Collectively, these authors have been reluctant to recommend that the government promulgate standards tied to either a specific COF value or to a specific definition of "slippery." As indicated earlier, their suggestions are directed towards the need to do additional research and development in the area. This can be seen by the following representative conclusions and recommendations selected from these six references. While these articles go back some 20 years, they still describe the current COF state of the art. Most of the following quotations address issues previously presented in the eight research questions.

\section{Federal Construction Council, National} Academy of Sciences (1961).

Select or develop a simple, portable device for field use in measuring slip-resistance . . Develop slip-resistance standards which consider locations and conditions of use . . Develop a set of standard reference surfaces which are economically reproducible; usable under field or laboratory conditions, and have long term stability/durability or are expendable ... Recommend maintenance procedures. (p. 12)

\footnotetext{
"Standards-related activities" means not only modifications to standards themselves but also any interpretive, directive, explanatory, or other informational material that might be developed by government or private sources for understanding or complying with standards.
} 
2. Reed, Comstock, and Wescott, Inc. (1975).

From results obtained using the Universal Friction Testing Machine, it was concluded that the COF for RMA rubber is extremely sensitive to the velocity at which the COF is measured... . The COF of leather is also sensitive to velocity but is less sensitive then rubber on an absolute scale .. . Leather produces dynamic values of COF which would generally be considered unsafe for the use of leather as the heels of shoes. (p. 54)

3. Pfauth and Miller, University of Michigan (1976).

Additional research is needed to determine: the forces that the foot exerts during various manual materials handling tasks; the additional slipping risk that occurs with increased age and/or decreased physical ability; the effect of different shoe designs; the friction requirements of mobile machinery; and what role psychological factors and preconceived biases play in slip type accidents. (p. 89)

\section{Brungraber, National Bureau of Stand-} ards (1976).

\section{a. Gravity of the Problem}

The seriousness of this (slip) problem has resulted in continuing research by the manufacturers of floor waxes and polishes, many shoe manufacturers and users, insurance laboratories and numerous government laboratories (state, federal and foreign). (p. 2)

\section{b. Kinesiology and Anthropometry}

It is clear that a walking surface can be too slippery to permit safe walking. It may also be that a walking surface could be too slip-resistant to permit safe, convenient walking . . . Thus, as was claimed by James, the most significant parameter controlling the slip-resistance of floors is the static coefficient of friction. (p. 3)

c. The General Study of Friction

A friction problem more directly related to floors is the increase in the static coefficient of friction with the increase in time delay between the application of the normal loads and the tangential or sliding load . . . this is caused by adhesion which in many cases is enhanced by the presence of water between the sliding surfaces. This may well be the explanation for the increase in coefficient of friction of leather soles by wetting that has been observed by many investigators . . . This points up the need for a friction measuring device that closely approximates the time delay that is representative of a normal step that is generally repeatable. (p. 4)

d. Appraisal of Methods for Determining Floor Slip Resistance

The pendulum type, as represented by the Sigler and the British Portable Skid Tester, measures only the dynamic friction and this as some sort of integrated function resulting in a mcasured energy loss of the pendulum . . . The dynamic coefficient of friction is not of prime importance in controlling slip resistance . . . The Hunter device has the disadvantage that it measures the dynamic friction ... The James machine does measure the static friction but for some reason, not explained in James' article, the final version of his device is strictly a laboratory machine suitable only for evaluating floor materials, not floors ... Many investigators have shown that within rather broad limits, the coefficient of friction between typical shoe and flooring materials is not sensitive to variations in contact pressure. (p. 5)

e. Guide for Selection of Slip-Resistance Criteria

There are three sources of information that can be used to select these values: (1) experimental kinesiology or measurement of the forces exerted by the shod foot upon the floor, (2) anthropometry or geometry of the walking body, and (3) friction measurements made on walking surfaces having known safety records. In setting recommended values for floor slip-resistance or static coefficient of friction it may well be that for 
certain walking maneuvers the friction could be too high and thus recommendations should be in the form of both upper and lower limits . . . Unfortunately the only fundamental evaluations of the static coefficient of friction have been made with the James machine and thus were made on flooring materials, not floors, and under controlled laboratory conditions, not in the field. Most field measurements have been made with either pendulum devices, such as the Sigler or the British Portable Skid Tester, or with the drag type devices such as the Horizontal Pull Slipmeter. (p. 7)

\section{f. Legal Aspects and Status of Specifica- tions}

There are several industries interested in the legal aspects of floor slip-resistance: the flooring manufacturers, the shoe manufacturers, the underwriters who insure buildings and the floor wax and polish manufacturers . . . The government specifications have been primarily developed by the military and are quite stringent, requiring that the coefficient of friction be as high as 0.7 in some cases. The other major contribution to floor slip resistance specifications has been a combined effort of the committee D2l of ASTM and the Scientific Committee of the Wax Division of the Chemical Specialities Manufacturers Association (CSMA). There has been considerable common membership in these two bodies and a great deal of cooperation between them . . . culminating in the recently published revision of the Standard Method of Test for Static Coefficient of Friction of Polish Coated Floor Surfaces as Measured by the James Machine (D2047-75). This revision now states "Floor polishes having a coefficient of static friction, measured by this method, of not less than 0.5 traditionally have been recognized as providing nonhazardous walkway surfaces. This value of not less than 0.5 meets the requirements for compliance to Rule 5 on 'The Use of the Terms Slip Retardant, Slip Resistant or Terms of Similar Im- port,' of the Proposed Trade Practice Rules for the Floor Wax and Floor Polish Industry as issued by the Federal Trade Commission on March 17, 1953." (p. 8)

\section{Adler and Pierman, National Bureau of} Standards (1979).

Existing standards and codes for walkway surfaces are generally vague and difficult to enforce since they lack quantitative definition of acceptable levels of slip resistance. The Center for Building Technology (National Bureau of Standards) is advancing research to permit the inclusion of quantitative criteria for slip-resistance now missing from voluntary standards and mandatory regulations . . . An extensive series of tests of commonly encountered walking surfaces has been conducted at selected locations including. . . data for common floor materials including polished and worn wood, terrazo, marble, concrete and vinyl-asbestos tile will be provided. Both wet and dry measurements have been completed and a report will be published in $1979 .^{2}$ (p. 2 , p. 23)

\section{James, Rubber and Plastics Research} Association of Great Britain (1980).

For safety the coefficient of friction should increase as velocity increases, so that sudden and uncontrollable slipping cannot occur . . . Few of the test machines at present used for pedestrian friction are adequate for their purpose. Two types of testers are needed (a) a laboratory test for quality control of either footwear materials or flooring materials as appropriate, (b) a portable tester for checking installed floors and the effect of floor treatments. In either case only instruments capable of measuring over a range of test conditions, in particular a range of velocities, should be considered. In comparative tests some form of practical service test, such as the SATRA ramp, should be included. Whether any test has been accepted as

${ }^{2}$ I do not believe that the results of this study had been made available as of November 1982. 
a Standard Method by any country is irrelevant and acceptance of a test by a Standards Committee should not be taken as a measure of its correctness ... It is suggested that for quality control purposes some universally available standard material, such as plate glass be chosen, the appropriate friction characteristics for safety on such a surface being established initially by practical experiment . . . it is also necessary to define some universally available contaminant which bears some resemblance to the dirt or dust picked up by shoe soles in practice.

The above quotations concisely summarize the state of the art from primarily qualitative viewpoints. The subsequent section will turn to an analysis of the quantitative criteria that have been presented over the years.

\section{Typical Quantitative Results}

Among the areas raised by the eight questions presented earlier, three must be addressed before any further progress in standards or regulatory activities is made. Many practitioners would argue that it is of equal importance to answer the questions about dynamic vs. static COF and about the type of COF measurement machine to use. These issues, however, are not considered to be of the same level of priority as the final three questions:

6. What COF values are necessary to counteract the horizontal forces generated by a person's walking?

7. What COF values are necessary to prevent persons from slipping as a function of the type of task performed?

8. What COF values can one typically expect for various combinations of shoe soles, surfaces, and contaminant conditions (oil, water, and dirt)?

To address the above questions, a tabular summary of key quantitative findings and recommendations has been developed. These appear in Table 1.

The research findings in Table 1 are divided into five categories: (1) static COF with human subjects; (2) static COF with computer models; (3) static measurement of sur- face/sole combinations; (4) dynamic COF studies; and (5) requirements in existing standards.

Based on a review of Table $l$ and the data contained in it, the author concludes the following:

1. The minimum required static $\mathrm{COF}$ for normal pace walking unloaded on a level surface ranges between 0.2 and 0.4 depending on the author's research methodology and to some extent on the type of walking (straight vs, turning left or right).

2. The required COF to prevent slipping is highly task-dependent. Walking up or down ramps, pushing or pulling loads, or even fast walking or running will require $\mathrm{COF}$ values much higher than those required for unloaded, normal pace walking on a level surface. For certain tasks, values of $\mathrm{COF}$ as high as $0.8-0.9$ might regularly be required.

3. Leather soles/heels are almost always much poorer than rubber in anti-slip qualities. The decrease in COF value from rubber to leather may be as much as 0.5 under comparable conditions.

4. Nearly all combinations of dry and clean shoes and surfaces have COF values greater than 0.5 while only selected combinations of wet shoes and surfaces result in a COF value greater than 0.4 .

5. The most common recommended COF by standards organizations and by individual authors is 0.5 . This value seems reasonable since it allows a small margin of safety over and above the $0.4 \mathrm{COF}$ which was often cited as needed for walking. None of these authors suggested that their recommendations be extended to tasks other than walking.

Having reviewed the qualitative and quantitative findings in the literature, and having drawn some conclusions, let us now turn to the application of some of these conclusions to future research and standards related activity.

\section{RECOMMENDATIONS}

\section{A Definition of Slippery Work Surfaces}

Nowhere in the literature was the author able to locate an operational definition of a "slippery" work surface. The necessity for 
TABLE 1

QUANTITATIVE COF RESULTS AND RECOMMENDATIONS FROM SELECTED AUTHORS

\begin{tabular}{|c|c|c|}
\hline \multicolumn{3}{|c|}{$\begin{array}{l}\text { "STATIC" COF RESULTS-HUMAN SUBJECTS } \\
\text { REQUIRED COF TO WALK MEASURED }\end{array}$} \\
\hline Reference & Coefficient Value $(\mathrm{f})^{\mathrm{a}}$ & Comment \\
\hline $\begin{array}{l}\text { University of California }(1947) \\
\text { cited in Brungraber }(1976, \text { p. } 8)\end{array}$ & $f=0.5$ at heel touch down & $\begin{array}{l}\text { Lapse time photography revealed } \\
\text { no slip (no dynamic movement) } \\
\text { during walking. }\end{array}$ \\
\hline $\begin{array}{l}\text { Cunningham }(1950) \text { cited in } \\
\text { Brungraber }(1976, \text { p. } 15)\end{array}$ & $\begin{array}{l}\text { f for walking: } \\
\text { level }=.25-.33 \\
\text { upstairs }=.15 \\
\text { downstairs }=.15 \\
\text { up ramp }=0.3 \\
\text { down ramp }=0.4\end{array}$ & $\begin{array}{l}\text { Subjects were used but measure- } \\
\text { ment device not specified; research } \\
\text { aimed at artificial limb design }\end{array}$ \\
\hline $\begin{array}{l}\text { National Bureau of Standards } \\
\text { (1951) cited in Brungraber (1976, } \\
\text { p. 17) }\end{array}$ & $\begin{array}{l}f=0.2 \text { at heel touch down } \\
f=0.4 \text { at toe leaving }\end{array}$ & $\begin{array}{l}\text { Electronic "stepmeter" measured } \\
\text { subjects walking; similar to cur- } \\
\text { rent force platforms. }\end{array}$ \\
\hline Johnson $(1958$, p. 204) & $\begin{array}{l}f=0.2-0.3 \text { for walking } \\
f>0.5 \text { recommended }\end{array}$ & $\begin{array}{l}\text { Electronic "stepmeter" designed by } \\
\text { NBS used; first publication listing } \\
\text { f }>0.5 \text { as recommended standard. }\end{array}$ \\
\hline $\begin{array}{l}\text { Harper et al. }(1961) \text { cited in } \\
\text { Brungraber }(1976, \text { p. } 20)\end{array}$ & $\begin{array}{l}f=.36 \text { straight walk } \\
f=.40 \text { turn, left foot } \\
f=.36 \text { turn, right foot }\end{array}$ & $\begin{array}{l}\text { Measurements made using force } \\
\text { plate which subjects walked over. }\end{array}$ \\
\hline $\begin{array}{l}\text { Schuster }(1966) \text { cited in } \\
\text { Brungraber }(1976, \text { p. 13) }\end{array}$ & $f>0.6$ on $15 \%$ grade & $\begin{array}{l}\text { Used "included plane" tester; con- } \\
\text { cluded subjects felt surface to be } \\
\text { "slippery" if } f>0.6 \text { while walking } \\
\text { up and down } 15 \% \text { incline. }\end{array}$ \\
\hline $\begin{array}{l}\text { Carlsoo (1972) cited in } \\
\text { Brungraber }(1976, \text { p. } 23)\end{array}$ & $\begin{array}{l}f=.23 \text { mean for walking } \\
f>0.5 \text { recommended }\end{array}$ & $\begin{array}{l}\text { Force plate used to measure } 100 \\
\text { subjects walking; recommended } \\
\text { value to make slipping "nonexist- } \\
\text { ent," }\end{array}$ \\
\hline $\begin{array}{l}\text { Perkins (1978) cited in James } \\
(1982, \text { p. 13) }\end{array}$ & $\begin{array}{l}\text { Landing phase: } \\
\text { Average }=.24 \\
\text { Maximum }=.28 \\
\text { Take-off phase: } \\
\text { Average }=.30 \\
\text { Maximum }=.39\end{array}$ & $\begin{array}{l}\text { Force plate tests with subjects } \\
\text { walking; values are for } \mathrm{H} / \mathrm{V}\end{array}$ \\
\hline
\end{tabular}

"STATIC" COF RESULTS- HUMAN SUBJECTS

MAXIMUM OR RANGE OF FORCE CAPABILITY MEASURES

\begin{tabular}{ccc}
\hline Reference & Coefficient Value $(f)^{\mathrm{a}}$ & Comment \\
\hline
\end{tabular}

Kroemer \& Robinson (1971, p. 25) Maximum static push/pull capa-

bility for given $\mathrm{COF}$ range:

$\begin{array}{ll}0.2<\mathrm{f}<0.3 & 25 \mathrm{lb} \\ \mathrm{f}=0.6 & 45 \mathrm{lb} \\ \mathrm{f}>0.9 & 70 \mathrm{lb}\end{array}$

Lee (1982, p. 132)

$$
\mathrm{f}>0.9 \quad 70 \mathrm{lb}
$$

$\mathrm{f}=0.2-0.8$ depending on force exerted and height of handle used for push/pull test.
COF values were arbitrarily fixed to determine how much push/pull force could be exerted by subjects at that level of COF.

Force platform used to measure $\mathrm{H} / \mathrm{V}$ ratios associated with range of push/pull forces at different handle heights.

\begin{tabular}{ccc}
\hline \multicolumn{3}{c}{ "StatiC" COF Results-Mathematical/COMPUTER Models } \\
\hline Reference & \multicolumn{1}{c}{ Coefficient Value $(\mathrm{f})^{\mathrm{a}}$} & \multicolumn{1}{c}{ Comment } \\
\hline Ekkebus \& Kelley (1973, p. 44) & $\begin{array}{l}\mathrm{f}=.298-.44 \text { based on } \\
\text { biomechanical model's stride }\end{array}$ & $\begin{array}{l}\text { Author accepts } \mathrm{f}>0.5 \text { "conserva- } \\
\text { tive" recommendation for a stand- } \\
\text { ard with a "reasonable" safety } \\
\text { factor. }\end{array}$
\end{tabular}

(continued) 
TABLE 1

QUANTITATIVE COF RESULTS AND RECOMMENDATIONS FROM SELECTED AUTHORS (CUI.)

\begin{tabular}{lll}
\hline \hline Riley \& Arnold (1978, p. 13) & $\begin{array}{l}\mathrm{f}=.378 \text { male } \\
\mathrm{f}=.418 \text { female }\end{array}$ & $\begin{array}{l}\text { Friction value below which the } \\
\text { hip moment can no longer be zoro } \\
\text { based on link system biomechani- } \\
\text { cal model. }\end{array}$
\end{tabular}

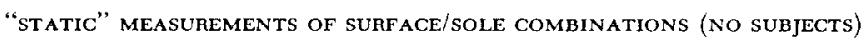

\begin{tabular}{ll}
\hline Reference & \multicolumn{1}{c}{ Coefficient Value (f) } \\
\hline Sigler $(1943$, p. 12) & $\begin{array}{l}\mathrm{f}>0.4 \text { for rubber heels (based on } \\
\text { heels and floors available at time } \\
\text { of test) }\end{array}$
\end{tabular}

Sigler et al. (1948, p. 346)

Kroemer \& Robinson $(1971$, p. 31) Overall means:

$\mathrm{f}(\mathrm{dry})=.69$

$\mathrm{f}($ soiled $)=.52$

Chaffin \& Andres $(1982$, p. 41) $\quad \mathfrak{f}=0.4-0.8$
"Slippery" if $\mathrm{f}<0.4$

Most dry combinations result in $\mathrm{f}>0.5$

Few combinations have $f>0.4$ when wet
Comment

About 30 floor materials were tested in lab using leather vs. rubber heels under dry, wet, clean, dirty, and soapy conditions; same pendulum tester used to measure effects of wax finishes.

Portable pendulum tester used on actual in-service floors with some lab tests also; 20 surfaces tested wet and dry against leather vs. rubber heels; leather almost always poorer than rubber. Some authors (i.e., James) contend this pendulum tester actually measures dynamic friction; thus the Sigler "antislip" coefficient is really a dynamic COF value.

"Slider" type sled tester used; 12 flooring specimens in combination with eight soling specimens were measured; dynamic COF was found to be close to static during preliminary tests; therefore, only static was measured in tests; soiled conditions defined as "oil and water."

Ten floor surfaces in six plants studied using leather and combination soles; Bigfoot, Slipometer, and Brungraber machines compared including some lab combinations; up to $40 \%$ differences among readings for three COF machines; wetted surfaces had highest variability among machines used.

\begin{tabular}{|c|c|c|}
\hline \multicolumn{3}{|c|}{ "DYNAMIC" COF RESULTS INCLUDED IN DATA } \\
\hline Reference & Coefficient Value $(f)^{a}$ & Comment \\
\hline \multirow[t]{2}{*}{$\begin{array}{l}\text { Barrett (1956) cited in Brungraber } \\
(1976, \text { p. 11) }\end{array}$} & $\begin{array}{l}f=0.497 \text { for walking } \\
f>1.077 \text { for running }\end{array}$ & $\begin{array}{l}\text { Analytically determined as being } \\
\text { required using "neutrally sus- } \\
\text { pended table." }\end{array}$ \\
\hline & $\begin{array}{l}f(\text { static })=0.6-0.7 \\
f(\text { dynamic })=0.7-0.8\end{array}$ & $\begin{array}{l}\text { Recommended COF for ideal } \\
\text { soling material under normal dry } \\
\text { and wet conditions. }\end{array}$ \\
\hline James $(1982$, p. 20) & $\begin{array}{l}\text { Kinetic COF should rise above } 0.6 \\
\text { at some low velocity }\end{array}$ & $\begin{array}{l}\text { Pendulum tester used to measure } \\
\text { "dynamic" COF; Sigler ( } 1943 \text {, } \\
\text { 1948) considers this apparatus as a } \\
\text { ineasure of what lie calls the "anti- } \\
\text { slip coefficient"; tests for rubber }\end{array}$ \\
\hline
\end{tabular}

(continued) 
static COF were unrepeatable; this suggested that rubber has only a dynamic COF which is dependent on velocity; Recommended that best static test is ramp test.

\begin{tabular}{|c|c|c|c|}
\hline Reference & Coeffici & alue $(f)^{a}$ & Comment \\
\hline \multirow[t]{2}{*}{$\begin{array}{l}\text { Bunten (1967) cited in James } \\
(1982, \text { p. 14) }\end{array}$} & $\begin{array}{l}\text { Skid } \\
\text { resistance } \\
\text { reading }\end{array}$ & $\begin{array}{c}\text { Floor } \\
\text { conditions }\end{array}$ & $\begin{array}{l}\text { Greater London Safety Council } \\
\text { Architects Dept. used skid test } \\
\text { (ramp) to establish these limits. }\end{array}$ \\
\hline & $\begin{array}{l}f<19 \\
f=20-39 \\
f=40-74 \\
f>75\end{array}$ & $\begin{array}{l}\text { dangerous } \\
\text { marginal } \\
\text { satisfactory } \\
\text { excellent }\end{array}$ & \\
\hline Underwriters Laboratory (1974) & \multicolumn{2}{|c|}{$\begin{array}{l}f>0.5 \text { as measured by James } \\
\text { machine }\end{array}$} & $\begin{array}{l}\text { Proposed method for determining } \\
\text { slip resistance of Floor Treatment } \\
\text { Materials (FTM) } 1,2,3,4,5,6 \text {; also } \\
\text { applies to Walkway Construction } \\
\text { Materials (WCM). }\end{array}$ \\
\hline $\begin{array}{l}\text { Edosomwan \& Khalil (1981, } \\
\text { p. 31) }\end{array}$ & \multicolumn{2}{|l|}{$\begin{array}{l}f>0.5 \\
f>0.7\end{array}$} & $\begin{array}{l}\text { Based on other references, author } \\
\text { cites } f>0.5 \text { as being common } \\
\text { divide point between slippery and } \\
\text { nonslippery; some military stand- } \\
\text { ards require } f>0.7 \text {. }\end{array}$ \\
\hline $\begin{array}{l}\text { American Society for Testing } \\
\text { Materials (ASTM-D2047-75, } \\
1975, \text { p. 1) }\end{array}$ & \multicolumn{2}{|l|}{$\mathrm{f}>0.5$} & $\begin{array}{l}\text { "Floor polishes having static COF } \\
\text { as measured by this method [using } \\
\text { the James machine] of not less } \\
\text { than } 0.5 \text { traditionally have been } \\
\text { recognized as providing nonhaz- } \\
\text { ardous walkway surfaces." }\end{array}$ \\
\hline $\begin{array}{l}\text { American Society for Testing } \\
\text { Materials (ANSI/ASTM-0489-77, } \\
\text { 1977) }\end{array}$ & \multicolumn{2}{|l|}{ No value given } & $\begin{array}{l}\text { Method for measuring sole and } \\
\text { heel materials using James ma- } \\
\text { chine; standard makes no state- } \\
\text { ment as to an acceptable value nor } \\
\text { that this method corresponds to a } \\
\text { particular type of friction coef- } \\
\text { ficient. }\end{array}$ \\
\hline $\begin{array}{l}\text { American Society for Testing } \\
\text { Materials (ANSI/ASTM E303-74, } \\
\text { 1978) }\end{array}$ & \multicolumn{2}{|l|}{ No value given } & $\begin{array}{l}\text { Method for measuring surface } \\
\text { "frictional" properties using British } \\
\text { Pendulum Tester; no values are } \\
\text { given for what are acceptable re- } \\
\text { sults. }\end{array}$ \\
\hline
\end{tabular}

"Coefficient Value ( $f$ ): This depends on the particular author's data as to its meaning. It generally refers to "static" coefficient of friction, but is also called "slip-resistance criteria" and "anti-slip coefficient." Where it means dynamic $\mathrm{COF}$ it is so noted. The machine used to collect data is critical in establishing the " $\mathrm{f}$ " value.

having one should be obvious. Ultimately, a quantified measure of "slippery" is needed for any specific application. In general, however, one must begin with a definition having performance criteria. Such a definition is proposed below.

"Slippery" must be defined in terms of the task being performed in addition to the inter- actions that occur among shoes, surfaces, and contaminants. Thus, the following "performance" definition is proposed:
A "slippery work surface" is that com- bination of (1) a host transient surface (such as a shoe or tire), (2) an agent structural surface (such as a floor, step, 
or ramp), and (3) contaminant conditions (such as water, oil, or dirt), all of which together have the propensity to cause the initiation and/or promotion of sliding between the host and agent surfaces during the performance of actual or anticipated tasks.

This definition is proposed as being technically correct and universally applicable. It is intended to serve as a guideline for specifying the factors for which quantified criteria would be provided in particular applications.

As a start in providing such criteria, the following is suggested. For the walking unloaded task on level surfaces, a "static" COF of about 0.5 for the shoe/surface interaction appears to be consensually acceptable as a quantitative standard. It is also slightly higher than the minimum COF of 0.4 that initial research has shown to be required by the physical walking process. One cannot use this value, however, without pointing out the limitations of the research from which it comes. In particular, these studies did not include humans initiating or terminating walking tasks or performing tasks involving the carrying of heavy objects. Rather, the COF value of 0.5 should primarily be thought of in terms of a walking unloaded task. Higher values of required $\mathrm{COF}$ can probably be anticipated as task-oriented and load-carrying research is done. Any standards utilizing a 0.5 COF must thus be flexible enough to allow for findings from future task-related research. Nevertheless, we should not wait for such findings before initiating changes to clarify the incomplete and unclear standards now existing.

Any agency having a definition/standard for a "slippery work surface" must also provide for the emerging role of dynamic friction in future standards. For example, standards for combinations of conditions that yield high dynamic COF or an increasing dynamic COF with velocity should eventually replace a fixed COF standard. The above definition for "slippcry" provides for such alternative "performance." It will also hopefully encourage new materials technology that addresses the role of dynamic COF in "stopping an initiated slip from continuing."
While this paper addresses "slippery" in relation to slip/fall accidents, the definition is also applicable to other types of slipping that may lead to accidents. For example, a forklift truck that can slip out of control and hit people, structures, or machines is another potentially dangerous work situation. Neither research nor standards in this country have given attention to these other types of slipping hazards in the work environment; nor have they addressed slipping hazards in the consumer environment such as the possibility of a portable cooking appliance slipping off a countertop and burning the user or the user's child. These examples reinforce the point that the primary research on slipping has almost exclusively addressed the pedestrian walking situation. Nevertheless, attention must also be focused on the nonpedestrian and nonoccupational areas. While outside the scope of this paper, they are a significant part of this author's research activities.

\section{"Nonslip" vs. "Slip-Resistant"}

The Federal Trade Commission (FTC Rule 5) has made it clear that terms such as "nonslip" and "nonskid" are not to be used to describe surfaces or surface coatings. Such terms are inappropriate because from a strict legal interpretation they suggest that a person will never slip on such surfaces no matter what the conditions - an impossible promise! Nevertheless, many of these terms are currently used frequently in OSHA and ANSI standards. It would be preferred, if not mandatory, to eliminate the use of such terms in favor of descriptors such as "slip-resistant," "slip-retardant," or "skid-resistant."

From the same legal source (i.e., FTC Rule 5) there is also some precedent for the use of a static COF of 0.5 as the quantitative dividing line between "slippery" and "slipresistant." Although this value was initially determined from walking research, it would not be surprising to find it misapplied during litigation to other than walking accidents. It appears, therefore, that there is some urgency to thoroughly research the required $\mathrm{COF}$ for many other types of work (and nonwork) tasks besides walking. The alternative is to have the criterion 0.5 universally hrust upon us for all conditions and tasks. 
Field Determination

\section{of Coefficient of Friction}

The issue of field determination of COF values may never be satisfactorily resolved if "on-the-spot" measurements of COF are regularly required for all work places. Currently available friction measuring devices, including the portable ones, are primarily intended for research and are not "off-the-shelf" quick reading digital gauges. Thus, their application should be limited to the more sophisticated employers and users.

On the other hand, it seems reasonable to provide employers with tabularized quantitative guidelines of approximate COF values for various shoe sole, heel, surface, and contaminant conditions. Approximating a COF value using tables may seem overly simple in lieu of developing universal friction measurement devices and would probably not satisfy the accuracy criteria of the purists. Nevertheless, this approach may be sufficient for a great many employers' situations. It would certainly be a big gain over the current situation of not knowing if they comply or how to comply! Currently, such tables exist in the literature in a limited way as scattered research results from different authors using different measurement devices. A deliberate effort to bring these findings together in a form useful to employers seems justified. From a cost-benefit standpoint, this would ultimately be more useful than developing special machines to be used by employers to measure their specific work surface COF values. The proposed tables could even now be included as informational material in or as appendices to safety standards. It is emphasized that these values would only yield an approximate COF. By using them, however, the employer would know the likelihood of his situation being hazardous compared to quantitative criteria within a standard.

\section{Recommended Actions on Standards}

The above material suggests that a given shoe, surface, or contaminant condition has a particular COF associated with it; on the other hand, a given task has a minimum required COF to accomplish it without slipping. This is really a restatement of the law of physics that in order to keep a body in equilibrium, a force acting on it from one direction must be countered with an equal and opposite force. Therefore, standards for COF can be written as requirements dependent on (1) the type of task to be performed (the originating force) or (2) the ability of the shoe/ surface combination to exert an equal and opposite force (the reactionary force). An employer could therefore achieve compliance by either (1) controlling the combination of shoe/surface/contaminant condition to which the worker is exposed or (2) controlling the type of task being performed with a given shoe/surface/contaminant condition (for which the COF is known). Either method of control should be accepted as complying with the intent of the standard.

Suggestions for alternative approaches to standards are presented in the following list. It summarizes those points presented earlier that could be acted upon by government/ consensus organizations now without any significant additional research.

1. Provide a performance definition of a "slippcry work surface."

2. Define "slippery" vs. "slip-resistant" surfaces using a quantitative static COF value. For level surfaces with employees walking unloaded, this could reasonably be 0.5 . (Loaded vs. unloaded will have to be defined.)

3. Change inappropriate descriptor terms such as "non-slip" and "non-skid" to "slipresistant."

4. Modify standards to emphasize that COF or "slip-resistant" requirements can be met by controlling the type of shoe, type of task, or amount of contaminant as an alternative to controlling only the COF of the work surface and its coating.

5. Insert informational material in standards or their appendices to indicate approximately (1) what COF is required by the task being performed and (2) what COF can be expected for a given type of shoe sole/heel, work surface/coating, and contaminant condition.

6. Emphasize in the standards the serious slip hazard that exists when work surfaces are contaminated with water, oil, and dirt because of poor process control or housekeeping. 
7. Suggest to employers the difficulty they will have complying with the standard if leather shoe soles and heels are permitted on wet or contaminated surfaces.

\section{Summary of Recommendations}

The need for this paper came about because concern and attention to "slippery" work surfaces have been almost entirely absent from both consensual and mandatory standards. The contents should have convinced the reader that there has been considerable research on shoe/surface slipperiness over the past 50 years that has immediate application to occupational safety. Nearly all of this research and its applications, however, center on pedestrian walking and level pedestrian walkway surfaces. There has been little attempt to apply even this information to occupational work surfaces. Coefficient of friction standards do not even exist for walkways used regularly by workers in pedestrian movement. One might thus conclude that 50 years of research on the role of the coefficient of friction in slips and falls has contributed little to remedying this problem area where about one in five work accidents occurs.

The issues on which research has focused were summarized at the beginning of this paper using eight questions. These questions continue to be timely as future research areas are considered. The literature dealing with these issues was summarized in two ways. First, qualitative recommendations were presented from the six papers which seem to best represent the consensus of findings. A general conclusion was that the use of coefficient of friction measurements appeared to be the best indicator of the propensity for slip/ fall accidents to occur.

Second, quantitative $\mathrm{COF}$ results were summarized in Table 1 for those studies from which quantitative conclusions could be drawn. These studies pointed to the importance of considering not only the type of flooring material but also the types of task, shoe soles, and contaminant conditions. Undertaking additional research in the areas of climbing, descending, twisting, stopping, starting, pushing, pulling, and lifting seems particularly justified.

As a result of the Table 1 analysis, governmental regulatory actions were suggested that can be taken at this time. Among the recommendations was that a coefficient of friction standard for work surfaces could be justifiably set at 0.5 for the shoe/surface/ contaminant combination. This can confidently be applied only to persons walking unloaded on level surfaces, however. In order to set standards for other types of tasks and work situations, additional research is mandatory. Such additional research would not be complicated or difficult to undertake and could produce useful results within a short time.

Two issues regarding terminology were addressed. First, how does one define a "slippery work surface" in performance terms? There being no existing definition, the following was suggested for consideration: A "slippery work surface" is that combination of (1) a host transient surface (such as a shoe or tire), (2) an agent structural surface (such as a floor, step, or ramp), and (3) contaminant conditions (such as water, oil or dirt), all of which together have the propensity to cause the initiation and/or promotion of sliding between the host and agent surfaces during the performance of actual or anticipated tasks.

The second concern aboul terminology was the indiscriminate use of terms such as "nonslip" and "nonskid." Since no shoe/surface combination can ever be guaranteed to be absolutely "nonslip," these terms should not be used to describe surfaces, surface coatings, or shoe materials. Examples of more appropriate terms are "slip-resistant," "slipretardant," and "skid-resistant."

Finally, there are numerous unresolved and continuing issues in the slip/fall area, as suggested by the eight questions presented at the beginning of this paper. The author is not sympathetic, however, with those who continue to use the unresolved aspects of these issues as excuses for not applying what is now available to address the various slip/fall accident situations.

\section{REFERENCES}

Adler, S. C., \& Pierman, B. C. A history of walkway slip resistance at the National Bureau of Standards (NBS Special Publication 565). Denver: National Bureau of Standards, 1979. 
Allcott, G. A. Slips, trips and falls - Working surfaces and industrial stairs. Morgantown, WV: HEW, April 1979.

American Society for Testing Materials, Measuring surface frictional properties using the British pendulum tester (ANSI/ASTM E 303-74), 1974 (Reapproved 1978).

American Society for Testing Materials. Static coefficient of friction of polish-coated floor surfaces as measured by the James Machine (ASTM D 2047-75), 1975 (Reapproved 1981).

American Society for Testing Materials. Static coefficient of friction of shoe sole and heel materials as measured by the James Machine (ANSI/ASTM F 489-77), 1977.

Anderson, C., \& Senne, J. (Eds.) Walkway surfaces: Measurement of slip resistance (ASTM Special Technical Publication 649), 1978.

Barrett, G. F. C. Observations on the coefficient of friction of shoe soling materials. Rubber Journal, December $1,1956$.

Brungraber, R. J. An overview of floor slip-resistance research with annotated bibliography (NBS Technical Note 895). Washington, DC: National Bureau of Standards, January 1976.

Brungraber, R. J. A portable tester for the evaluation of the slip-resistance of walkway surfaces (NBS Technical Note 953). Washington, DC: National Bureau of Standards, July 1977.

Bunten, J. Friction measurements on soles and heels with particular reference to women's top-piece materials (SATRA Publication TM 1355), 1967.

Carlsoo, S. How man moves, Kinesiological methods and studies. London: Heinemann, 1972.

Chaffin, D. B., \& Andres, R. O, Evaluation of three surface friction measurement devices for field use. Ann Arbor: Center for Ergonomics and Safety, The University of Michigan, September 1982.

Cramp, P. A. Preliminary study of the slipperiness of flooring. Washington, DC: National Bureau of Standards, July 1974

Cunningham, D. M. Components of floor reaction during walking. Berkley: Institute of Engineering Research, University of California, November 1950.

Draganich, L. F., Andriacchi, T. P., Strongwater, A. M., \& Galanti, J. O. Electronic measurement of instantaneous foot-floor contact patterns during gait. Journal of Biomechanics, $1980,13$.

Edosomwan, J. A., \& Khalil, T. M. Accident prevention in slips and falls-A comprehensive approach. Professional Safety, June 1981.

Ekkebus, C. E., \& Kelley, W. Measurement of safe walkway surfaces. Soap/Cosmetics/Chemical Specialties, February 1973.

Elftman, H. Forces and energy changes in the leg during walking. American Journal of Physiology, 1939. 125

Fox, W. F. Body weight and coefficient of friction as determiners of pushing capability (Human Engineering Special Studies Memo No. 17). Georgia: Lockheed, August 1967.

Gavan, F. M., \& Vanaman, J. B. Significant variables affecting results obtained with the James Machine. Materials Research and Standards, November 1968.

Harper, F. C., Warlow, W. J., \& Clark, B. L. The forces applied to the floor by the foot in walking ( $\mathrm{Na}$ - tional Building Studies Research Paper No. 32). London: Department of Scientific and Industrial Research, Building Research Station, 1961.

Irvine, C. H., A new slipometer for evaluating walkway slipperiness. Materials and Research Standards, 1970, 10(4). (a)

Irvine, C. H. Shoe sole slipperiness on structured steel. Materials Research and Standards, 1970, 10(4). (b)

Irvine, C. H. Evaluation of some factors affecting meas urements of slip resistance of shoe materials on floor surfaces. Journal of Testing and Evaluation, 1976 , $4(2)$.

Jacobs, N. A., Skorecki, J., \& Charnley, J. Analysis of the vertical component of force in normal and patholngical gait. Journal of Biomechanics, 1980, 13.

James, D. I. A broader look at pedestrian friction. Rub ber Chemistry and Technology Review, 1980, 53.

James, D. I. Rubbers and plastics on shoes and flooring: The importance of kinetic friction. Shawbury, England: Rubber and Plastics Research Association of Great Britain, 1982.

James, D. I., \& Newell, W. G. A new concept in friction testing (Report No, 20). Shawbury, England: Rubber and Plastics Research Association (RAPRA), 1978 .

Johnson, B. S. A discussion of some factors influencing slip resistance measurements. Philadelphia: Franklin Research Company, May 1958.

Kroemer, K. H. E., \& Robinson, D. E. Horizontal static forces exerted by men standing in common working positions on surfaces of various tractions. Dayton, $\mathrm{OH}$ : Aerospace Medical Research Laboratory, Wright Fat* terson Air Force Base, January 1971.

Lee, K. S. Biomechanical modelling of cart pushing and pulling. Unpublished doctoral dissertation, Center for Ergonomics and Safety, The University of Michigan, 1982.

Manning, D. P. Deaths and injuries caused by slipping, tripping and falling accidents. England: University of Surrey, April 1982.

Miller, J. M. A bibliography of coefficient of friction literature relating to slip type accidents. Ann Arbor: Department of Industrial Engineering, University of Michigan, February 1983.

National Academy of Sciences. Causes and measurement of walkway slipperiness (NBS Technical Report No. 43). Washington, DC: Author, 1961.

National Bureau of Standards. Electronic step-meter reveals mechanics of walking. Technical News Bulletin, $1951,35(4), 50$.

National Safety Council. Falls (Education Data Sheet No. 5 , revised). Chicago: Author, ND.

Perkins, P. J. Measurement of slip between the shoe and ground during walking (Special Technical Publication No. 649). American Society for Testing Materials, 1978.

Pfauth, M. J., \& Miller, J. M. Work surface friction coefficients: A survey of relevant factors and measurement methodology. Journal of Safety Research, 1976, $8,77-90$

Reed, M. E. Standardization of friction testing of industrial working surfaces. Cambridge: Comstock \& Westcott Inc, 1975.

Riley, M. W., \& Arnold, R. C. Relating human static work of standing and the coefficient of friction be- 
tween the shoe and floor using a link-system model. Proceedings of the Human Factors Sociely - 22nd Annual Meeting, 1978.

Santos, $F$. Factors in detecting and correcting floor slipleriness. National Safety News, October 1966.

Schuster, K. Slip-An investigation of practical accident prevention. Die Berufsgenossenschaft, Betriebssicherheit, September 1966.

Sigler, P. A. Relative slipperiness of floor and deck surfaces (Report BMS 100). Washington, DC: Nationa Bureau of Standards, July 1943.

Sigler, P. A., Geib, M. N., \& Boone, T. II. Measurement of slipperiness of walkway surfaces. Journal of Research, National Bureau of Standards, 1948, 40, 339-346.

Solving the problem of unsafe surfaces begins with se- lecting correct flooring. National Safety News, August 1980.

Strandberg, L.., \& Lanshammer, H. The dynamics of slipping accidents. Journal of Occupational Accidents, $1981,3,153-162$.

Underwriters Laboratory, Outline of the proposed investigation for determining the slip resistance of floor treatment materials (Subject 410). New York: Author, January 1974.

University of California. Fundamental studies of human locomotion and other information relating to the design of artificial limbs (Report to National Research Council). Berkley: Author, 1947.

Wilson, A., \& Mahoney, P. Measuring functional prop. erties of soles and heels. Rubber World, March 1972. 